\title{
Pátio cercado por árvores de espinho e outras frutas, sem ordem e sem simetria: $O$ quintal em vilas e arraiais de Minas Gerais (séculos XVIII e XIX)
}

\section{José Newton Coelho Meneses ${ }^{1}$}

RESUMO: $O$ texto objetiva analisar os quintais urbanos e rurais em Minas Gerais, ao final do século XVIII e início do século XIX. Interpreta evidências documentais de inventários post mortem, narrativas de viajantes estrangeiros, documentos administrativos e iconográficos, interpretando esses espaços, na perspectiva da cultura material, como lugares de abastecimento alimentar, sociabilidades e da intimidade familiar. Considera a ligação dos quintais com a casa e as ruas e os vê como espaços de equilibrio da paisagem urbana.

PALAVRAS-CHAVE: Quintais. Cultura material. Minas Gerais.

ABSTRACT: This article analyses urban and rural backyards in Minas Gerais, in the late $18^{\text {th }}$ and early $19^{\text {th }}$ centuries. Sources include probate records, foreign travelers accounts, administrative documents and iconography. These spaces are interpreted as a part of material culture, as provisioning grounds, and places of sociability and family intimacy. The connections of yards within households and the surrounding streetscapes are examined, revealing that they can be viewed as instruments of balance in the overall urban landscape.

KEY WORDS: Backyards. Material culture. Minas Gerais.

(...) existe um porão da civilização, um domínio onde a rotina, a inércia, a consciência fraca estão em sua influência máxima, um espaço onde reina o silêncio sobre experiências comuns porém vividas majoritariamente no foro íntimo, uma temporalidade longa marcada por fracas rupturas, mudanças pouco visíveis, em que predominam os hábitos, os costumes, as tradições que escapam da datação fácil e das divisões sociais reconhecidas²
1. Professor Associado do Departamento de História da FAFICH - Universidade Federal de Minas Gerais. E-mail: <jnmeneses@uol. com.br>.

2. Cf. Daniel Roche (2000) 
3. Para uma história geral da casa ocidental, na perspectiva de sua materialidade, ver, dentre outros trabalhos, Daniel Roche (2000), especialmente a segunda parte do texto $A$ vida comum, capítulo IV Casas rurais, casas urbanas; Fernand Braudel (1995), especialmente o capítulo $4 O$ supérfluo e o costumeiro: o babitat, o vestuário $e$ a moda, em seu primeiro tópico Casas de todo o mundo. Para a cultura doméstica brasileira no período colonial ver Leila Mezan Algranti (1997) e Sheila de Castro Faria (1998).
Introdução

Dos quintais urbanos dos pequenos aglomerados populacionais das Minas Gerais do tempo colonial vêm sons de animais domésticos e de atividades de pessoas no trabalho. São os sons primordiais das vilas e dos arraiais. Das ruas, apenas as sonoridades eventuais de conversas de ocasião e de ruídos surdos de cascos de cavalos em arruamentos sem pavimentação de pedra - nenhum burburinho extraordinário. Esses sons prevalentes na paisagem das urbes coloniais, imaginados a partir da interpretação histórica, traduzem a importância dos quintais nas Minas Gerais do tempo em foco. Sons de ações, do trabalho, do convívio das pessoas, da produção; onde a vila é mais ativa.

Lugares de pomares e de hortas, das flores, das especiarias para temperos e das ervas medicinais, dos galinheiros e dos chiqueiros, de domesticidade e de contatos com a vizinhança, os quintais são espaços primordiais para se entender a cultura setecentista e oitocentista de Minas. Distintos da paisagem da rua, eles são os territórios de maior atividade das urbes e dão equilíbrio visual à paisagem dos aglomerados populacionais. No mundo rural, de forma distinta, complementam a rarefeita paisagem edificada e são secundários às atividades produtivas da roça.

Nos aglomerados urbanos ou nas fazendas, os quintais são extensões das casas. Talvez, melhor dizendo, são parte delas. Tomando-as com suas diversas funções - proteção, acolhimento, trabalho, relações familiares - as casas têm nos quintais o instrumental de boa parte dos papéis culturais a elas destinados nesse tempo. Os quintais não possuem apenas função laboriosa, mas encarnam aspectos fundamentais da construção do cotidiano familiar e das relações da família com a sociedade. Falar deles, então, implica em historiar essa ligação íntima do quintal com o edifício da casa ${ }^{3}$. No entanto, ainda, ele se liga à rua, mesmo que, ao contrário, não seja dela extensão ou parte. Sua relação com o espaço público é de ordem distinta: é sim, de intermediação.

Os quintais nesse espaço histórico apresentam-se como excelente perspectiva de pensar as relações sociedade/natureza na construção da materialidade cotidiana, em período da colonização das Minas Gerais setecentistas e oitocentistas. São, ainda, lugares que congregam um acervo de elementos materiais da cultura, denotando perspectivas construtivas dos espaços urbanos, suburbanos e rurais, no universo colonial do sertão americano.

$\bigcirc$ presente texto é uma interpretação preliminar e problematizadora sobre esse lugar domiciliar importante. Tal interpretação é evidenciada materialmente por documentos históricos que falam desse espaço. É, por outro lado, a busca de construção conceitual, ou seja, de explicação lógica e sistematizada sobre um lugar. Espaço, lugar, paisagem e território: expressões de significados complexos e de discussão interdisciplinar que serão de utilidade em nossa busca compreensiva. No momento, este texto tem objetivos menos amplos e não busca interpretar a amplitude das relações dos quintais com a casa 
e a rua e, menos ainda, as suas representações como espaço do homem na natureza. Neste artigo buscamos uma mínima caracterização dos quintais, para firmar o pé nesse lugar. Para tanto, escolhemos valorizar aqui as narrativas de dois viajantes que circularam por Minas Gerais nos primeiros vinte anos do século XIX - Auguste de Saint-Hilaire, naturalista francês, e John Mawe, mineralogista inglês -, uma pequena amostra de um conjunto de Inventários post mortem de moradores da Comarca do Serro Frio, no acervo da Biblioteca António Tôrres em Diamantina, algumas imagens produzidas por cartógrafo e pintores do período, além de, em forma diminuta e sintética, posto ser um conjunto documental de pesquisa e de análise em fase de andamento, documentos camarários das localidades em tela.

Essa documentação concretiza um importante diálogo entre fontes, de forma a permitir ao pesquisador acessar a materialidade de um tempo e a compreensão de uma cultura que a envolve e inclui. Os Inventários descrevem os bens e apõe valores e formas de uso que as narrativas corroboram ao descrever técnicas, configurações espaciais e ações humanas, complementadas pelas imagens. Essas últimas, da mesma forma, narram uma paisagem física e humana que se busca compreender na leitura do conjunto documental. A documentação camarária, diversa em seu conjunto, apresenta-nos o discurso ordenador e a ação administrativa fiscalizadora que nos mostra, sob outra perspectiva, as mesmas ações humanas, usos, técnicas, destinações, formas de ocupação do espaço e de relações sociais nele estabelecidas.

De antemão, é preciso compreender que a dicotomia cultura/natureza é insuficiente para a interpretação de espaços construídos. As noções de espaço, lugar, paisagem e território já trazem embutida a presença do homem na physis, transformando-a. Não há, para o historiador, a possibilidade de conceito de espaço sem a cultura e, assim, não é fundante a ideia de espaço natural em História. Os quintais, aqui considerados os urbanos e os rurais, então, são espaços complexos que exigem variáveis múltiplas na busca de sua definição. São lugares do homem em uma dada natureza construída.

Compreendamos, ainda, que não há, da mesma forma, para o historiador e para outros cientistas sociais, a dimensão do espaço sem a sua temporalidade, ou seja, espaço e tempo são categorias de análise indissociáveis e a complexidade espacial deve ser "medida" como escalas espaço-temporais que são múltiplas e socialmente construídas. São ampliados os ritmos da temporalidade no diálogo com a igual multiplicidade das escalas da espacialidade. Nesses múltiplos ritmos e escalas é que compreendemos a complexidade espacial nas integrações extensão/duração, continuidade/descontinuidade, unidade/ diversidade, permanência/mutação, ordenação/fluxo, finitude/infinitude, o absoluto e o relativo ${ }^{4}$. $\bigcirc$ espaço/quintal, lugar da família e território da domesticidade, em diálogo com a sociabilidade de vizinhança e com o mundo da rua, só pode ser pensado em uma temporalidade própria, em uma dimensão que não se restringe a marcos cronológicos.
4. Importante reflexão sobre o espaço como categoria de análise e em sua integração com o tempo podemos ver em Rogério Haesbaert (2006); Douglas Santos (2002); Marcio Freitas Eduardo (2006); Milton Santos (1985) e José Newton Coelho Meneses (2011). 
5. "Paisagem" é, da mesma forma, tomada aqui como a definem os mesmos autores referenciados que a conceituam, de modo geral e em tentativa de síntese, como a representação do espaço através da percepção dos sentidos humanos, historicamente construídos pelos valores temporais que se adaptam à cultura, interferindo nela e na própria representação do espaço. Esses valores e representações serão discutidos no texto avaliando principalmente as narrativas dos viajantes analisados e as imagens.

6. Cf. Daniel Roche (2000, p. 12-13).

7. Cf. Ibid. (p. 19).

8. Cf. Raphael Bluteau (1720), Vocabulario portuguez \& latino: aulico, anatomico, architectonico... <www.brasiliana.usp.br/ bbd/handle/1918/00299407\# page $/ 73 /$ mode/1up $>$. Acessado em $1^{\circ}$ maio 2015.

9. Cf. Ibid. (p. 74).

10. Cf. Ibid.

11. Já Antonio de Moraes Silva (1789, p. 543), em sua obra Diccionario da lingua portugueza, define "quintal" de forma mais sintética: "É na cidade ou vila um pedaço de terra murada com árvores de fruta, etc." < http://www. brasiliana.usp.br/pt-br/ dicionario/2/Quintal>. Acessado em $1^{\circ}$ maio 2015.
Aqui neste texto pensamos o quintal como um lugar, definido pelos estudiosos referenciados, em síntese, como o espaço onde se constroem relações humanas em uma dinâmica de tempo em que essas relações se manifestam em hierarquias e em valores distintos. Essas hierarquias e esses valores marcam os homens e conformam o próprio espaço. O quintal, como avaliamos, apresenta-se então como um lugar de conformações sociais que extrapolam o âmbito da família e são fundamentais na construção da paisagem ${ }^{5}$ urbana do período.

Como problema histórico há perspectivas elementares nos quintais que poderiam ser foco de análises múltiplas e, às vezes, paradoxais. Quando localizados no meio urbano são lugares onde o mundo/tempo rural se materializa de forma efêmera, embora contundente. Apresentam-se, por outro lado, como espaços de sociabilidade de vizinhança, marca/tempo de urbanidade. São, de outra forma, territórios da intimidade familiar e do recolhimento feminino e infantil. Abastecem a família e a vila na construção de uma culinária cotidiana, de um gosto alimentar próprio e no atendimento às emergências para preservar a saúde das pessoas da casa e daqueles do círculo familiar.

Esses lugares têm equipamentos e estruturas que denotam a prática de artes mecânicas e fabris, além de serviços ordinários. São lugares da banalidade cotidiana e dos objetos da vida comum. Banalidade na complexidade que a define Daniel Roche, citando F. Dagognet: "Qualquer objeto, mesmo o mais comum, contém engenhosidade, escolhas, uma cultura." ${ }^{\circ}$. E complementa o autor: "Um saber e um acréscimo de sentido estão ligados a todos os objetos."

De antemão e em síntese que nos norteia, quintais são pequenas quintas. Assim os definem os dicionários setecentistas e os contemporâneos. São construídos atrás das casas e se prestam, ao primeiro olhar, para suprir as demandas alimentares do domicílio e da vizinhança. São, como mencionamos, parte das moradas. Território da família. A quinta definida pelo Dicionário de Raphael Bluteau é "casa de campo ou fazenda de lavoura no campo com sua casaria. Chamou-se assim porque de ordinário o que arrenda a Quinta dá ao dono dela a quinta parte do que colhe em frutos"8. Já a definição de quintal, no mesmo dicionário setecentista, aponta-nos que "É na cidade pequena ou Vila um pedaço de chão com árvores frutiferas e cercado de muros. Chama-se quintal por servir como Quinta no povoado" 9 . Na sequência da definição Bluteau admite que "não é fácil achar-the nome próprio latino" porque "Hortus é jardim; Hortus olitorius é horta; Pomarium é Pomar, como também Viridarium é propriamente falando Quintal". O jesuíta dicionarista então, opta por acrescentar: "Mas a necessidade nos obriga a usar Viridarium ou Pomarium e sendo preciso se the poderá acrescentar Muro septum." 10. A definição do lugar, como toda busca de explicação, procura simplificar significados mais complexos. A nós, também, a necessidade leva-nos a admitir, como Bluteau, que não é fácil achar-the ajustada definição. Por sua complexidade, o que buscamos é compreender este espaço como lugar de certa importância na vida dos aglomerados urbanos ${ }^{11}$. 
Em um Inventário post mortem da região do arraial do Tejuco do início do século XIX, do conjunto de Inventários por mim pesquisado na Biblioteca António Tôrres, em Diamantina, Minas Gerais (nas referências abreviada como BAT), nos bens do inventariado Caetano Miguel da Costa, um viúvo, pai de seis filhos, o quintal de sua morada, na rua que sai para a Vila do Príncipe, é descrito como "pátio cercado e engenho com água dentro, árvores de espinho e umas outras frutas" $^{\prime 12}$. Na visão do naturalista francês Auguste de Saint-Hilaire, em visita à região no início do século XIX, são lugares "sem ordem e sem simetria". Ambos, o Inventário e a narrativa do viajante, são discursos construídos sobre nosso objeto que o caracterizam minimamente. Vamos, então, perscrutar essas narrativas.

arraial do Tejuco foi, ao final do século XVIII, a aglomeração urbana mais populosa da Comarca do Serro Frio, uma vasta região ao norte da Capitania de Minas Gerais. Possuía em nosso tempo de análise cerca de 6.000 habitantes, segundo a descrição de John Mawe, um viajante inglês que o visitou em 1809. Próximos ao arraial, Mawe descreve outras aglomerações urbanas que gravitavam em seu entorno e "muita população esparsa nas fazendas de agricultura e criação, nos campos, nas lavras auríferas e diamantinas" ${ }^{13}$.

A descrição do viajante inglês nos informa das áreas produtoras rurais, o que nos faz presumir uma importante atividade de abastecimento alimentar, da qual participavam, também, as chácaras nas proximidades do aglomerado e os quintais urbanos e rurais. $\bigcirc$ próprio Caetano Miguel da Costa, citado acima, possuía uma chácara no ribeirão do Inferno, bem próximo ao Tejuco, onde tinha "pastos de criar com próprias casas cobertas de capim". Da mesma forma, Mariana Joaquina Rosa possuía como propriedades imóveis "duas moradas de casas com seus quintais com água dentro" e uma "chácara no subúrbio", onde criava gado e possuía "três bestas de carga" que levavam seus produtos para o comércio no arraial $^{14}$. José Ribeiro da Silva possuía, de forma semelhante, casa nos arredores do arraial. Era "uma pequena casa e suas matas com uma senzala e casa de piar, paiol e uma engenhoca de moer mandioca"15. Em Gouveia, arraial próximo ao Tejuco, João José de Aquino era proprietário de "um sítio no Ribeirão do Chiqueiro", bem próximo à aglomeração, "com casas de vivenda cobertas de telha, paiol, moinho, árvores de espinho, bananeiras e capoeiras", onde, também, criava gado (dezessete cabeças) ${ }^{16}$. Todos esses espaços descritos, nas proximidades das casas ("fogos") participam de um processo produtivo de alimentos que envolve famílias.

Pensemos, antes de exemplificá-las mais em pormenor, sobre as narrativas dos dois viajantes estrangeiros que vamos expor neste artigo, feitas por Auguste de Saint-Hilaire ${ }^{17}$ e John Mawe. Dois homens de ciência do "século das luzes", tempo da construção das bases sistemáticas da exploração científica moderna da natureza, marcada não apenas pelas necessidades de conhecê-la e de dominá-la, já presentes depois do século XV, mas, sobretudo, de guardar o seu registro ${ }^{18}$. A partir do século XVIII é necessário apropriar-se da natureza "selvagem"
12. Cf. BAT (1810), Inventário $038,2^{\circ}$ Of., Maço 175. Existe na Biblioteca António Tôrres (BAT) um número descontínuo de Inventários post mortem da antiga Comarca do Serro Frio da Capitania de Minas Gerais. São esses 55 documentos que foram lidos in loco pelo autor do artigo.

13. Cf. John Mawe (1978, p. 150). John Mawe nasceu em Derbyshire (Inglaterra) em 1764 e faleceu em 26 de outubro de 1829. Foi um mineralogista que escreveu mais de dez trabalhos sobre mineralogia e geologia. Sua principal obra é On a Gold Mine in South America, que teve a primeira edição em 1812 com 9 estampas, uma delas colorida, e despertou grande interesse, sendo, em nove anos, lançada em segunda edição inglesa, nos Estados Unidos, além de ter tradução para o francês, italiano, holandês, sueco, alemão, russo e português. Depois de muitas experiências na região do Rio da Prata, fretou um barco em Montevidéu, com o qual navegou em direção ao norte por vários portos do Brasil, entre os quais o da ilha de Santa Catarina. Foi recebido no Rio de Janeiro por Dom João, com quem obteve autorização para visitar as jazidas de diamantes de Minas Gerais e do interior entre 1809 e 1810.

14. Cf. BAT (1806), Inventário $030,1^{\circ}$ Of., Maço 54.

15. Cf. BAT (1797), Inventário $011,1^{\circ}$ Of., Maço 33, com Testamento anexo.

16. Cf. BAT (1805), Inventário $043,1^{\circ}$ Of., Maço 47.

17. Auguste de Saint-Hilaire, botânico francês, veio para o Brasil em 1816 acompanhando a missão extraordinária do duque de Luxemburgo, que buscava 
resolver o conflito entre Portugal e França quanto à posse da Guiana. Suas relações pessoais alçaramno a ter patrocínio do Museu de História Natural de Paris e financiamento do Ministério do Interior para permanecer no Brasil, onde fica até 1822 .

18. Sobre os viajantes naturalistas no Brasil oitocentista é primordial ver, dentre vários estudos: Lorelai Kury (2001; 2004; 2004a; 1995); Ana Maria Beluzzo (1994); José Carlos Barreiro (2002); Miriam Moreira Leite (1997) e Karen Macknow Lisboa (2000).

19. Além das narrativas de Auguste de Saint-Hilaire e de John Mawe foram investigadas as descrições de outros viajantes estrangeiros pelo território de Minas Gerais no século XIX. No entanto, essas outras narrativas não serão consideradas neste texto. São os viajantes: James W. Wells, W. L. Eschwege, Richard Burton, John Luccock e George Gardner.

20. Cf. John Mawe (1978, p. 159).

21. Cf. Ibid. (p. 161). dos trópicos, e, além disso, conhecer o homem "inferior" que vive nela. "Inferior" porque menos tocado pela civilização e com menor espírito das realizações históricas do homem do "velho mundo". Essa é, ao que denota suas narrativas, uma ideia hegeliana forte, presente nestes dois homens.

A base que fundamenta esse conhecimento é o empirismo enraizado em 2 eixos claros: o registro do novo e a sua ordenação. São homens herdeiros de Humboldt e de Linné. Nomear o mundo natural e classificá-lo é dar a prova da capacidade humana de conhecer, memorizar e apropriar. Saliente-se que essa construção sistemática não ocorreu de forma tão simples como apresento aqui. Ela foi fruto de embates complexos e de pensamentos díspares como as ideias do conde de Buffon e as de Jean-Jacques Rousseau, para tomar apenas um exemplo. No entanto, culminam na preconização do conhecer, registrar, ordenar e apropriar. Auguste de Saint-Hilaire é, no contexto do início do século XIX, o protótipo do cientista exigido pelo meio científico de Paris: o homem capaz de pensar no gabinete e sair dele para o exercício do campo.

Ambos, Saint-Hilaire e Mawe sabem construir narrativas e elas têm valor fundamental para a pesquisa sobre os quintais. As narrativas de Saint-Hilaire, principalmente, que considero mais preocupado com a acuidade descritiva própria dos naturalistas, são sensíveis e atentas, criteriosas e críticas. Neste sentido, contrario um pouco a frequente e incidente crítica à essas descrições. Reconheço que para a temática dos quintais, os discursos construídos por este naturalista, especialmente, mas, também, por outros, a despeito da estranheza ao mundo exótico e do pensamento sobre a inferioridade da cultura, são atentas à manifestação desse homem no cultivo da natureza e a veem como possibilidade de conhecimento sobre este "mundo natural", como o descrevem. Dessa forma apresentam-se mais aderidas ao ideal de compreensão e de registro e menos articuladas a um conceito previamente construído de inferioridade cultural. Às vezes a percepção reconhece originalidades funcionais nos quintais e as apresenta como possibilidades de aprendizado para o homem europeu. ${ }^{19}$

Na leitura crítica destes dois viajantes estrangeiros que passaram pelo território da Capitania de Minas Gerais (depois Província de Minas Gerais, a partir de 1815) é clara a referência aos quintais e à sua importância. John Mawe diz sobre o mesmo Tejuco a que nos referimos acima, que é um aglomerado urbano "no declive de uma montanha, irregularmente construído. As ruas são desiguais, mas as casas em regra são benfeitas e bem conservadas, em comparação com outras cidades do interior" 20 . Os quintais das casas observados por ele são abundantes de "laranjas, abacaxis, pêssegos, goiabas e existe uma variedade de frutas indígenas, doces e ácidas, principalmente a jaboticaba, cheia de substância mucilaginosa". Neles, ainda, "o gengibre e a pimenta crescem espontaneamente e com certeza cultivam-se várias especiarias com resultado" 21 .

A jabuticaba ("indígena", no dizer do viajante), fruta da jabuticabeira (Myrcia cauliflora), é de origem sul-americana, espontânea em grande parte do Brasil, com grande frequência em Minas Gerais. É mais comum em regiões de 
clima subtropical úmido, existindo em diversas variedades (12 a 15). A de frutos maiores é a mais comum em Minas. É uma fruta exclusiva de pomares domésticos, não se encontrando plantações comerciais de jabuticabeiras. Explica isso a precariedade da conservação de seus frutos. Sendo muito fermentável - a fermentação da jabuticaba é processo acelerado poucas horas depois de colhida - é apreciada para feitura de geleias, vinho e licores. O tempo de sua safra tornase, assim, um período de intensa mobilização não só no gosto em apreciar a fruta, mas, também, na busca de fatura de seus produtos derivados. A jabuticaba do quintal é uma marca simbólica das regiões centrais de Minas e a fruta denota forte expressão da cultura doméstica mineira. É árvore de porte médio a grande, dependendo da variedade, e seus frutos, tipo baga, são redondos e de coloração roxo-escura, com polpa esbranquiçada e muito doce. É comum, em função das características de sua colheita difícil (que exige capacidade e destreza em subir nas árvores) e de sua periodicidade anual muito aderida à estação das águas, tornar-se, em seu tempo de frutificação, motivo para encontros de pessoas em torno do quintal. Representa e simboliza, nessa tradição transformadora do evento natural em cultural, a "mineirice", a domesticidade, o "familismo" e, em síntese, o quintal das Minas.

A observação e valorização das frutas cultivadas ou nativas no Brasil, no período da colonização portuguesa, foi motivadora de muitos comentários de cronistas e de administradores. Sobre a jabuticaba, Frei Antônio do Rosário, em seu texto metafórico sobre as frutas do Brasil, publicado em Lisboa, em 1702, informa que não é aconselhável o consumo da fruta pelos membros do clero. Diz ele:

De jabuticabas livre Deus aos pastores do rebanho de Cristo; são como uvas ferraes, têm a raiz fora da terra. A cobiça é a raiz de todos os males: Radix enim omnium malorum est cupiditas; ainda mal porque o mundo diz e clama que o interesse está na lgreja e se é tão pública e notada a raiz da cobiça, os mamões e umbus são as frutas que servem para a obrigação dos Pastores Eclesiásticos, e não a Jabuticaba com as raízes de fora representando os interesses demasiados, as cobiças insaciáveis: Radix enim omnium malorum est cupiditas ${ }^{22}$.

Para além dos mamões e umbus, Frei António do Rosário indica como fruta própria para os padres o caju, que, segundo seu texto, une duas frutas em uma só: a castanha e a polpa. Para ele, ambos "mostram a união, a paz e a concórdia que têm ou devem ter entre si"23. $\bigcirc$ caju não é uma fruta comum nos quintais das Minas. Nada a inferir, no entanto, sobre a paz, a concórdia e a união dos pastores de Cristo no espaço setecentista mineiro. Isso não é nosso objeto. Voltemos aos quintais.

Os relatos dos viajantes que passavam pelos caminhos, roças e aglomerados urbanos das Minas Gerais ressaltam uma hospitalidade seletiva e a boa qualidade da alimentação dos mineiros. Segundo alguns deles, essas características são explicadas pela formação doméstica das mulheres e por suas
22. Cf. Frei António do Rosário (1702, p. 110-111). A grafia da referência foi modernizada.

23. Cf. Ibid. (p. 111-112) 
24. Cf. Auguste de SaintHilaire (1975, p. 96).

25. Cf. Id. (1850, p. 335). Tradução feita pelo autor do original digitalizado da Bibliothèque Nationale de France. No original francês da edição referida: Les femmes se montrent, à Villa do Príncipe, plus que partout où j'avais eté jusqu'alors. Dans presque toutes les maisons où je visites, l'on me présenta aux dames, et il me fut permis de causer avec ells; mais je ne saurrais vanter leur beauté autant que leur politesse.

26. Cf. Ibid. (p. 337). Tradução feita pelo autor do original digitalizado da Bibliothèque Nationale de France. Em francês: les plus touchantes de bienveillance et amitié e sa maison était ouverte à tout le monde.

27. Cf. Ibid. (p. 328).

28. Cf. Id. (1975, p. $145-$ 146). capacidades de administrar o cotidiano e de manter os quintais com diversidade de plantas. $O$ quintal e a cozinha seriam prolongamentos naturais um do outro, lugares de intimidade e de recolhimento da família, e essa característica seria a responsável pela hospitalidade da região. Auguste de Saint-Hilaire nos diz que

O interior das casas, reservado às mulheres, é um santuário em que o estranho nunca penetra, e pessoas que me demonstravam a maior confiança jamais permitiram que meu criado entrasse na cozinha para secar o papel necessário à conservação de minhas plantas; era obrigado a acender o fogo fora, nas senzalas ou em algum alpendre. Os jardins [quintais] sempre situados por trás das casas, são para as mulheres uma fraca compensação de seu cativeiro, e, como as cozinhas, são escrupulosamente interditados aos estrangeiros ${ }^{24}$.

A hospitalidade seletiva e a reserva das mulheres têm variações graduadas, de acordo com o naturalista viajante, de lugar para lugar. Ele narra: "As mulheres se mostram, na Vila do Príncipe, mais que nos lugares onde estive até agora. Em quase todas as casas que visitei, fui apresentado às damas e me foi permitido conversar com elas." Complementa dizendo: "Mas eu não posso elogiar tanto sua beleza quanto sua polidez"25. Já a hospitalidade do Padre Francisco Rodrigues Ribeiro de Avellar, em casa do qual se hospedou "por quase um mês", Saint-Hilaire descreve como uma recepção com "a melhor boa vontade e amizade" que poderia ter, complementando que a casa do cura, a despeito da simplicidade dos móveis, era "uma casa sempre aberta a todo mundo" 26.

Nas traduções das narrativas de Saint-Hilaire usadas originalmente como fontes para esta análise a palavra "jardim" foi usada para traduzir o texto original francês que, efetivamente utiliza a palavra "jardin". Mesmo que o narrador explique que são "Os jardins sempre situados por trás das casas" (Les jardins toujours situées derrière les maisons, no original) ${ }^{27}$ o que nos leva a associá-los ao que a cultura portuguesa e brasileira conhece como "quintais", a opção dos tradutores foi mantida neste texto em respeito à fonte utilizada. $\bigcirc$ naturalista francês, descrevendo a Vila do Príncipe, informa-nos, ainda:

[As] Casas estão no mesmo nível que a rua; como, porém, estão construídas em terreno inclinado, foi necessário procurar algum meio de conserva-lhes o nível, e nada se encontrou de mais prático do que apoiá-las pela parte traseira sobre colunas muito elevadas. (...) cada casa possui um pequeno jardim [quintal] em que se plantam, sem ordem, bananeiras, mamoeiros, laranjeiras, cafeeiros, e se cultivam, a mais, couves e algumas espécies de cucurbitáceas ${ }^{28}$.

Territórios de materialidades e de sociabilidades

Os achados documentais sobre os quintais permitem ao historiador uma interpretação consistente das vivências no período que definimos para estudar. Eles nos evidenciam as coisas e nos motivam a vê-las como fatos sociais. As estruturas construídas no espaço doméstico do interior da morada, e em contato com outra domesticidade 
vizinha e com a rua, aponta-nos formas de produzir e viver de dimensões complexas. Interessa-nos esses objetos e esses artefatos, os gestos que os utilizam e as sociabilidades que os vivenciam. Queremos perceber as vivências de quem os usam, a economia que os fundamentam, as identidades em que eles se inserem. As coisas dos quintais são instrumentos de experiências humanas. São elementos materiais da cultura alimentar, da vivência familiar, da domesticidade, da sociabilidade, da economia provedora do cotidiano dos habitantes das Minas setecentistas e nos permitem inferir sobre a história colonial desse sertão português na América para além de seus quintais, de suas cozinhas, de suas mesas e de suas moradas ${ }^{29}$. Como nos diz Arlette Farge, citando Hourdard e Thierry, "compreende-se melhor os indivíduos e as comunidades explorando as múltiplas relações desses com os diversos 'não humanos'"30.

Ao interpretar os viajantes, outros documentos que veremos a seguir e as permanências da tradição do interior de Minas Gerais, os quintais são espaços de cultivo, de criação, de fazeres e de sociabilidades. Harmonizam-se aí canteiros de hortaliças, pomar de frutas (de espinho, mucilaginosas, goiabeiras, bananeiras), produção de ervas medicinais, especiarias para temperos e conservação dos alimentos, espaço para cucurbitáceas (abóboras e morangas), criação de porcos e de aves para o consumo domiciliar e pequeno comércio do excedente. Lendo os Inventários post mortem do período setecentista, podemos acrescentar como seus componentes eventuais as engenhocas, os moinhos d'água (se o quintal tem "água dentro") e os teares, onde a arte feminina transforma as fibras do algodão em "pano mineiro".

As permanências na cultura popular mineira podem apresentar limites que, no processo histórico, transformaram o espaço das cozinhas em lugar não mais interditado ao visitante. Ao contrário, a hospitalidade mineira, hoje, convida a pessoa bem-vinda para o ambiente do fogão e do preparo dos alimentos. $\bigcirc$ quintal, entretanto, permanente nas cidades interioranas, é território da família, das atividades mais domésticas e da intimidade cúmplice dos "da casa".

Voltando ao século XVIII, mas permanecendo no Tejuco ${ }^{31}$, podemos observar em mapa do período setecentista, a importância dos quintais na conformação do espaço urbano. $\bigcirc$ documento, de autoria de António Pinto de Miranda (Figuras 1 e 2), é datado de 1784 e encontra-se no Arquivo Histórico do Exército, no Rio de Janeiro. A aquarela colorida é representação de um momento de intensa produção cartográfica sobre a região da Demarcação Diamantina, desde 1772, sob o regime de monopólio da extração de diamantes pela Real Extração, subordinada à Diretoria dos Diamantes, em Lisboa.

A Planta do Arraial do Tejuco apresenta-nos uma paisagem urbana dominada pelos quintais. Aquarelados em cores e distinções evidentes na técnica do artista, mesmo sem legendas, permitem-nos a interpretação de espaços diferenciados e diversos. São pomares, hortas e seus canteiros de múltipla destinação, vegetações distintas (bananeiras, cucurbitáceas, etc.), estruturas edificadas afastadas da morada de residência ou do edifício eclesiástico que podem representar lugares de criação de suínos e de galináceos, ou mesmo espaços para engenhocas e moinhos.
29. É vasta a discussão historiográfica sobre cultura material. Aqui me restrinjo à temática deste texto para referenciar poucos estudos que foram primordiais para pensar os quintais e a casa Assim, ver: Vânia Carneiro de Carvalho (2011); Ulpiano Bezerra Toledo de Meneses (1983, 1998); Daniel Roche (2000); Arlette Farge (1986, 1992, 2015); Vincent Milliot (2014) e Tristan Garcia (2011).

30. Cf. Arlette Farge (2015, p. 9, tradução nossa). No original em francês: ont peut mieux comprendre (...) les individus et les collectifs bumains en explorant les multiples relations que ceuxci entretiennent avec de très divers 'non humains.'

31. Hoje, cidade de Diamantina. 


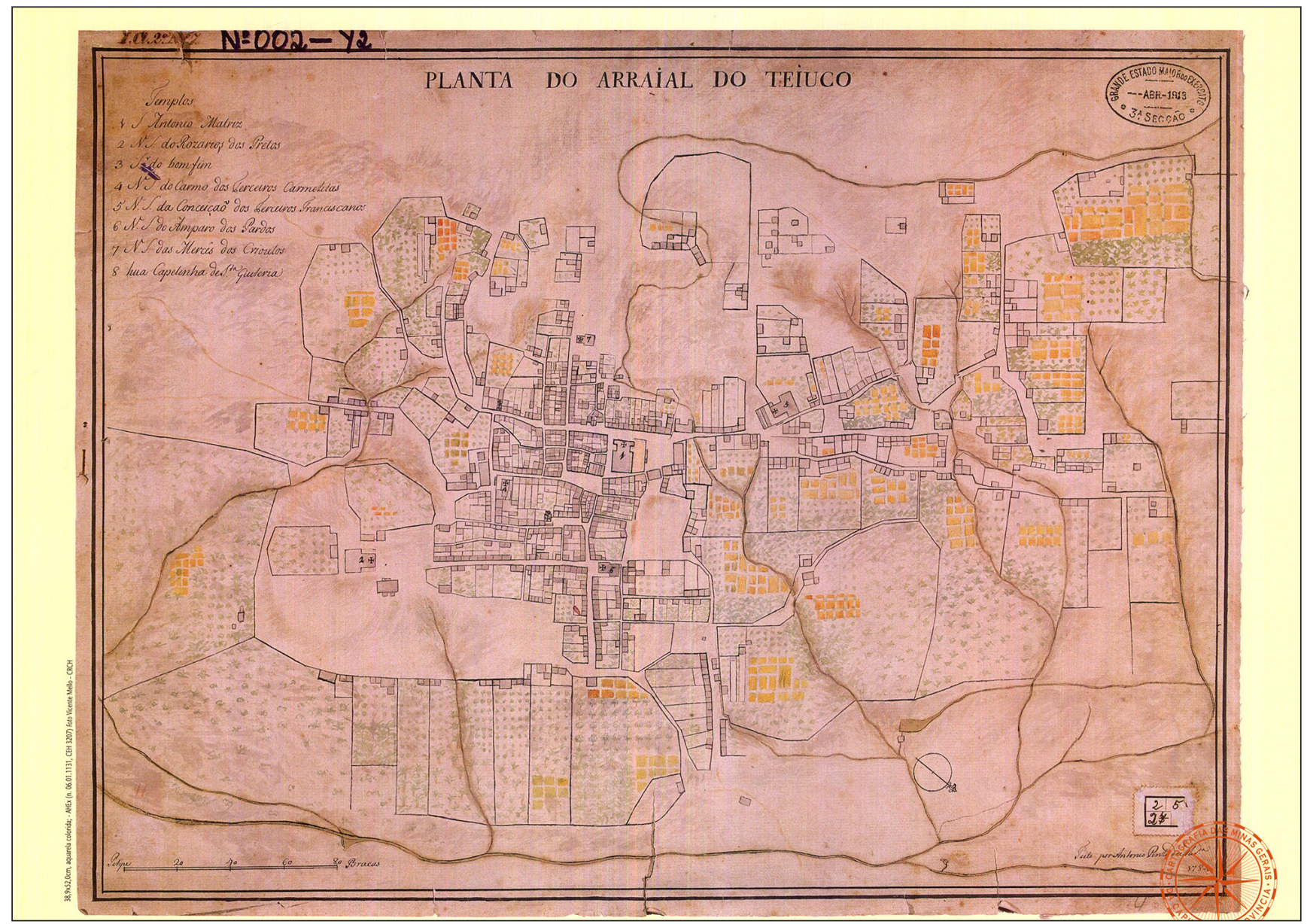

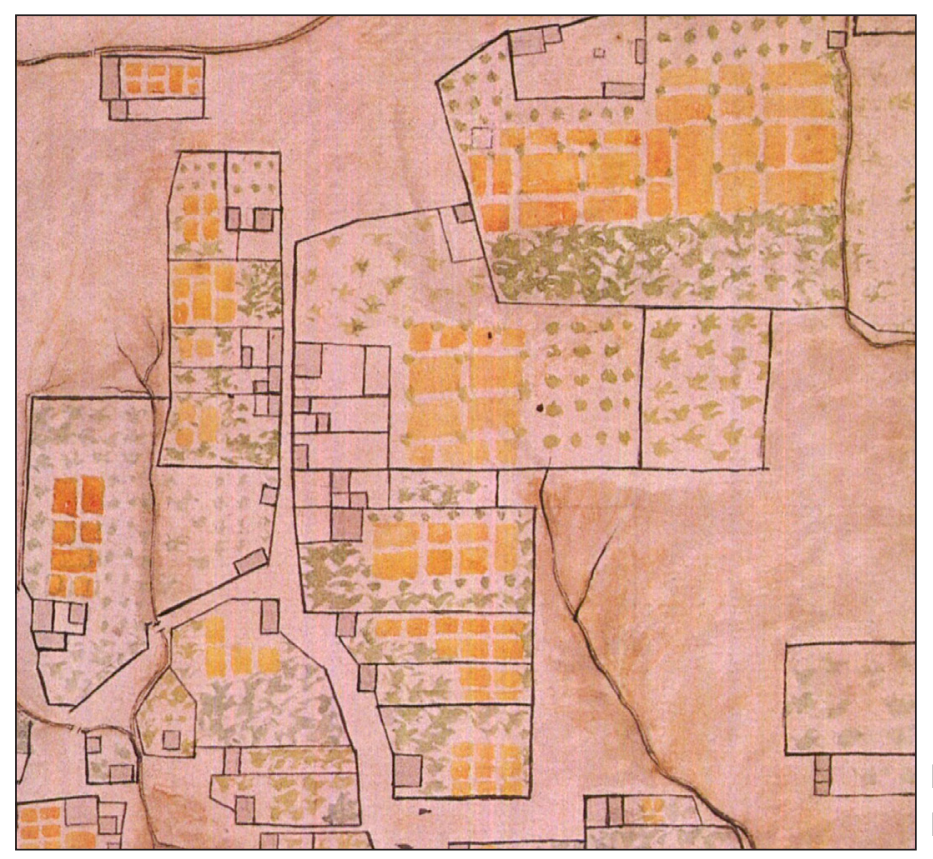

Figura 1 - António Pinto de Miranda. Planta do Arraial do Tejuco, 1784, aquarela colorida, 38,9×52cm, Arquivo Histórico do Exército/RJ. Fonte: Costa; Renger; Furtado \& Santos, 2002.

Figura 2 - Planta do Arraial do Tejuco. Detalhe. Fonte: Costa; Renger; Furtado \& Santos, 2002. 
Mesmo as igrejas possuem áreas em seu entorno que prenunciam um quintal de abastecimento próprio. É o caso, por exemplo, das representações da Igreja de Nossa Senhora do Rosário dos Pretos e, mais claramente, da de Nossa Senhora da Conceição dos Terceiros Franciscanos, como no detalhe a seguir (Figura 3).

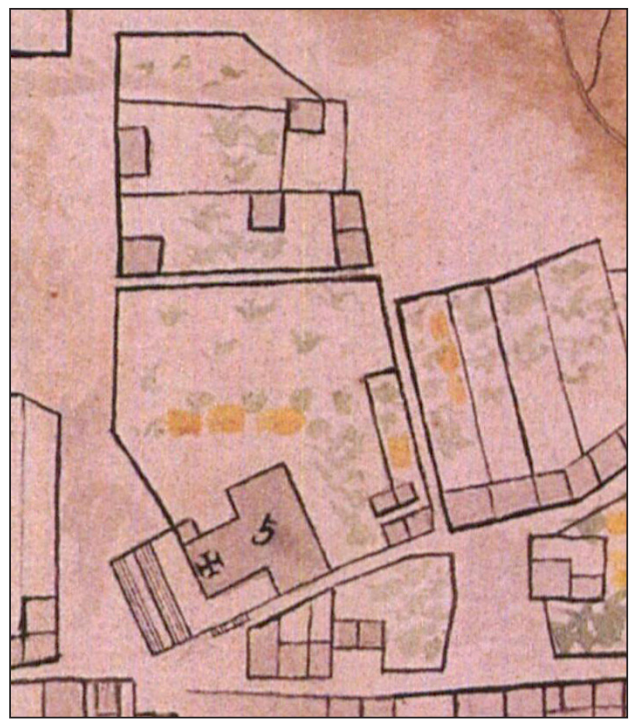

Figura 3 - Planta do Arraial do Tejuco. Detalhe referente ao edifício e quintal da lgreja de Nossa Senhora da Conceição dos Terceiros Franciscanos. Fonte: Costa; Renger; Furtado \& Santos, 2002.

Também edifícios da administração possuíam seus quintais com utilidades inequívocas. É o que nos demonstra, por exemplo, o requerimento do carcereiro de Vila Rica, António de Serqueira, que em 3 de janeiro de 1747 solicita à Câmara a permissão e as providências para construir "nos quintais da mesma cadeia, uma casa que possa servir de enfermaria de alguns presos de enfermidades graves". Para ele "as reformas nos quintais" seriam de custo baixo e teriam grande utilidade para salvar esses enfermos. $\bigcirc$ documento nos leva a pensar que os quintais do edifício público eram providos de ervas medicinais à disposição da futura casa de enfermaria ${ }^{32}$.

A julgar pela Planta do Tejuco, é possível interpretar um pleno abastecimento de verduras, legumes, ervas medicinais, especiarias para temperos, abóboras e morangas, além de frutas de espinho e de outras variedades, carnes de porcos e de frangos, dada a grande quantidade de áreas demarcadas como canteiros, pomares, chiqueiros e galinheiros. Quanto mais se afasta da concentração central do arraial, maiores são as pequenas quintas no espaço interior das áreas domiciliares urbanas. A Planta e a descrição dos viajantes dão-nos conta de espaços equilibrados entre edificações, arruamentos e vegetação dos quintais, com harmonia na construção da paisagem dos aglomerados, permitindo a visão das "perspectivas muito agradáveis" a que se refere Saint-Hilaire.

A respeito do quintal de uma casa mais afastada do centro do arraial do Tejuco, John Mawe nos informa:

32. Cf. Arquivo Público Mineiro, Câmara Municipal de Ouro Preto (1947, cx. 19, doc. 48). 
33. Cf. John Mawe (1978, p. 221), referência à casa do $\mathrm{Sr}$. Ferreira da Câmara.

34. Existem exceções: já há algum tempo Cláudia Damasceno Fonseca vem trabalhando com o espaço urbano e periurbano de aglomerações populacionais em Minas Gerais no período em tela e inspirado trabalhos monográficos importantes. São pesquisas que apresentam o processo de urbanização em uma complexidade espacial maior, configurando melhor a dinâmica de estruturação dos aglomerados populacionais em uma dimensão dialógica entre a physis e a sociedade. Ver Cláudia Damasceno Fonseca (1998, p. 27-66); Cláudia Damasceno Fonseca (2003), editado no Brasil como Cláudia Damasceno Fonseca (2011). Há ainda trabalhos como o de Sérgio Ricardo da Mata (2000) e Fabiano Gomes da Silva (2007) que têm a mesma perspectiva. Outros estudos importantes sobre abastecimento de água nas vilas mineiras evidenciam essas estruturas para além das edificações civis, administrativas $\mathrm{e}$ religiosas, tidas como mais importantes, salientando as buscas humanas na configuração da vida material na cidade, como Denise M. Ribeiro Tedeschi (2014) e Marjolaine Carles (mimeo). Além desses, alguns trabalhos sobre Minas Gerais em suas configurações urbanas trazem perspectivas da cultura material e são atentos ao cotidiano de formação dos aglomerados, como é exemplo, dentre outros, de Maria Aparecida de Menezes Borrego (2004).

35. Este texto é o primeiro produto monográfico reflexivo de uma pesquisa que se desenvolve há alguns anos $O$ quintal nas Minas Gerais nos séculos XVIII $e$ $X I X$ e que, como projeto acadêmico, envolveu no
Ao lado, via-se belo jardim, de perto de três acres, cheio de relva; fora outrora uma lavagem. Em toda sua superfície, viam-se detritos e pedras. $\bigcirc$ atual proprietário o aplainou, pôs-the um pouco de terra e aí semeou uma espécie de gramínea, que corta para os seus animais. Estávamos no começo da estação das frutas. Os pêssegos, em árvores carregadas, se aproximavam da maturação. $\bigcirc$ aspargo e outras hortaliças eram ótimos ${ }^{33}$

Precisaríamos, em outro momento, que este artigo não se adequa a refletir sobre a construção da cidade na região das Minas Gerais, considerando a importância dos quintais, o desenho de sua apresentação, a sua inserção na physis e no universo sociocultural da aglomeração que surge e se constrói no século XVIII. Aí dialogaríamos com os historiadores das cidades e perceberíamos a relevância dos quintais no planejamento das construções urbanas e na disposição do espaço das urbes de Minas. Penso que os historiadores intérpretes de nossas cidades coloniais ainda não problematizaram suficientemente a presença dos quintais e os espaços de abastecimento alimentar no interior dos arraiais, das vilas e das cidades do período. A insistência em ver estruturas edificadas e seus valores funcionais e estilísticos tem deixado para um segundo plano de interesse espaços de arruamentos e conformações estruturais onde se implantam os edifícios ${ }^{34}$.

Algumas pressuposições, no entanto, já se adiantam à luz da documentação pesquisada ${ }^{35}$. Nelas percebemos a importância da construção da paisagem urbana e do equilíbrio entre espaços edificados e "vazios" de composição vegetal. Para exemplificar, continuemos com os relatos coevos e com o espaço do arraial do Tejuco. Auguste de Saint-Hilaire nos diz em sua visita de 1817 :

Os jardins são muito numerosos e cada casa tem, por assim dizer, o seu. Neles vêem-se laranjeiras, bananeiras, pessegueiros, jabuticabeiras, algumas figueiras, um pequeno número de pinheiros (Araucaria brasiliensis) e alguns marmeleiros. Cultivavam-se também couves, alfaces, chicórea, batata, algumas ervas medicinais e flores, entre as quais o cravo é a espécie favorita. Os jardins do Tijuco parecem-me geralmente melhor cuidados que os que havia visto em outros lugares; entretanto eles são dispostos sem ordem e sem simetria. De qualquer modo resultam perspectivas muito agradáveis dessa mistura de casas e jardins dispostos irregularmente sobre um plano inclinado. De várias casas vêem-se não somente as que ficam mais abaixo, mas ainda o fundo do vale e os outeiros que se elevam em face da vila; e não se poderá descrever bem o efeito encantador que produz na paisagem o contraste da verdura tão fresca dos jardins com a cor dos telhados das casas e mais ainda com as tintas pardacentas e austeras do vale e das montanhas circundantes ${ }^{36}$.

Aqui se ressalta o que chamei atenção acima: há a expectativa dos jardins e a decepção com a "desordem e falta de simetria" dos quintais, mas há, por outro lado, a verificação cuidadosa (e elogiosa) da paisagem natural no contraste com a cultivada e com a edificada.

Como vemos, as flores, também, compõem a paisagem dos quintais. A despeito delas, não podemos pensar em espaços traçados à esquadro e régua com a simetria dos jardins públicos europeus, como a Planta do Tejuco acima demonstra. Falando de flores, ainda no Tejuco, SaintHilaire descreve: 
As plantas ornamentais cultivadas nos nossos jardins e transportadas ao Tijuco, tais como os cravos, o botão-de-ouro, a saudade, a margarida, o amor-perfeito, florescem principalmente nos meses de outubro e novembro, e parece que mudando as fases dos seus ciclos as diferentes espécies continuaram a manter os mesmos intervalos entre as respectivas épocas de floração; porque é em setembro que a anêmona floresce e em agosto a violeta ${ }^{37}$.

A julgar pela percepção do naturalista há uma certa indistinção entre o quintal urbano e aqueles de casas de fazendas por onde passou. Saindo do Tejuco e encaminhando-se para Vila Rica, ele caracteriza o quintal da casa de Intendência na Vila de Sabará e o cuidado com as pragas que poderiam diminuir sua produção:

A sede da Intendência do ouro, velho edifício de um andar, acha-se em ruínas; mas seu pomar é notável em relação a essa região. É atravessado, em seu comprimento, por uma aléia guarnecida, de cada lado, por uma fileira de laranjeiras cujos troncos são circundados por um vaso de barro cheio de água; isso é usado para impedir às formigas, muito comuns em Sabará, de subir às árvores e devorar as folhas ${ }^{38}$

As formigas, considerando uma preocupação presente ao longo da história, sempre foram problema para quintais e plantações no nosso meio. Elas são endêmicas nas Américas e são comuns no sul dos Estados Unidos, na América Central e na América do Sul (com exceção do Chile). Esses animaizinhos poderosos pertencem à classe dos insetos e à ordem himenóptera. No Brasil, são doze espécies do gênero Atta, sendo que cinco delas são comuns em Minas. Em sua simbiose com os fungos, as formigas têm atividade forrageira, que inclui seleção, corte e transporte de folhas e brotos das plantas para o interior do ninho. Esse material vegetal vai alimentar os fungos e o pavor de todo agricultor ou cultivador de plantas nos quintais e nas roças ${ }^{39}$. Esses insetos "sociais", em suas formas temporárias aladas (as fêmeas içás ou tanajuras e os machos bitus) ou permanentes (rainha e operárias - jardineiras, cortadeiras e soldados), são para os quintais pragas a serem combatidas ininterruptamente. Nos séculos XVIII e início do XIX e na tradição dos quintais mineiros, cercar as árvores frutíferas e plantas de jardim com estruturas contendo água é combate mecânico eficiente contra os insetos e salva a produção dos quintais, como nos narra o naturalista francês.

Saindo de Sabará na direção de Vila Rica, o viajante Saint-Hilaire hospeda-se na fazenda de Henrique Brandão Barbosa, distante três léguas e meia da Vila sede da Comarca do rio das Velhas. O quintal rural não the passa despercebido:

Antes de eu deixar a fazenda, o alferes Barbosa levou-me ao seu jardim, que é muito grande e irrigado, por todos os lados, por pequenos regos. Esse jardim não apresenta, aliás, mais do que grandes canteiros onde são cultivadas hortaliças, separados por fileiras de laranjeiras e diferentes espécies de jabuticabeiras. Tal é o sistema adotado na Província de Minas Gerais, nos jardins a que são dados maiores cuidados ${ }^{40}$. primeiro momento, além do pesquisador responsável, alunos em processo de Iniciação Científica. Neste sentido, agradeço a pesquisa documental no Arquivo Público Mineiro e a leitura de relatos de viajantes estrangeiros realizadas em momentos distintos pelos estudantes bolsistas Cássio Bruno Rocha, Gilmar Rodrigues Pereira Júnior, Henrique Brener Vertchenko, Davi Aroeira Kacowisk e Paulo Renato Andrade Silva. Agradeço ainda a Regina Horta Duarte a oportunidade de discussão conceitual importante no início do projeto.

36. Cf. Auguste de SaintHilaire (1974, p. 28, grifo nosso).

37. Cf. Ibid. (p. 32-33).

38. Cf. Ibid. (p.75)

39. Ver Valéria Mara da Silva (2007).

40. Cf. Auguste de SaintHilaire (1974, p. 78). 
41. Sérgio Buarque de Holanda já registrava em sua análise sobre a sociedade da região mineradora o gosto pelos doces de frutas e a prática comum na região de produzi-los em variedade. Ver Sérgio Buarque de Holanda (1993).

42. Cf. Auguste de SaintHilaire (1974, p. 83, grifo nosso).

43. A tradição mantém a produção de marmeladas e goiabadas em São Bartolomeu até os nossos dias. Ela ainda apresenta, no geral, como qualidade, a falta de transparência e a técnica de fazer o doce com sementes e, às vezes, até com a casca (como é o caso da goiabada cascão).
Urbanos, periurbanos, ou rurais, os "jardins" são expressão de uma forma peculiar de se relacionar com o mundo natural presente em todas as culturas e que nas Minas Gerais vão assumir características próprias. Espaços preservados pela família, eles são o lugar da ação cotidiana de seus membros, da harmonia do trabalho e do aprendizado infantojuvenil.

Os pomares dos quintais urbanos e rurais são a fonte primordial de um processo caro à cultura do abastecimento alimentar e do gosto culinário nas Minas Gerais, construído desde os primeiros tempos da ocupação de nosso território. Eles fornecem a matéria-prima para os doces de ocasião, que mantêm as frutas conservadas pelo açúcar para o consumo cotidiano das famílias e o abastecimento das demandas dos aglomerados urbanos fora de suas estações. Em São Bartolomeu, numa pequena localidade no percurso de Saint-Hilaire em direção a Vila Rica, depois de passar por Sabará, os quintais se apresentam como lugares especiais para essa produção ${ }^{41}$. Ele nos diz sobre a chácara de João Henriques:

A região onde se acha situado o rancho, sendo muito alta, não tem temperatura elevada. As macieiras e os marmeleiros aí dão muitos frutos e a colheita de marmelos é mesmo de grande importância para a aldeia de S. Bartolomeu, cabeça de paróquia, situada a 1 e meia légua de João Henriques. Não há, disseram-me, uma pessoa em S. Bartolomeu que não tenha um quintal plantado de marmeleiros e macieiras; os habitantes fazem com os marmelos um doce muito afamado que é posto em caixas quadradas feitas com uma madeira branca e leve chamada caixeta e não somente vendem essas caixas em Vila Rica e seus arredores, mas ainda fazem remessas ao Rio de Janeiro. Comi desses doces; eles têm pouca transparência, porque não há o cuidado de eliminar as sementes e o miolo; mas têm gosto quase tão agradável quanto as famosas marmeladas de Orleans. Os marmelos que se colhem nesta região aproximam-se menos da forma de uma pêra que da maçã, e não têm a mesma acidez dos nossos. Quanto às maçãs acredito que serão muito boas, se as deixarem amadurecer, pois há o mau vezo de colherem-nas verdes. De resto não é somente em S. Bartolomeu que se plantaram macieiras; elas são plantadas também nos arredores de Vila Rica e na Serra de Capanema ${ }^{42}$

Aqui a comparação dos doces de São Bartolomeu com os de sua cidade natal, Orleans, mesmo que tecnicamente depreciativa, é elogiosa. Note-se que essa depreciação desconsidera a possibilidade de um gosto alimentar próprio ao explicar a razão da ausência de transparência na massa do doce de marmelo ${ }^{43}$.

O viajante valoriza a descrição dos quintais e os vai caracterizando e surpreendendo-se com novidades por onde passa. No caminho para Congonhas do Campo, daí para São João d'El Rei, passando por Lagoa Dourada, Prados e pela Vila de São José (Tiradentes) são muitas as perspectivas de análise e descrições que o fazem apresentar espécies por ele desconhecidas, como a Araucaria brasiliensis e a Acrocomia sclerocarpa (Macaúbas). Em 1819, quando já se completavam 3 anos de sua permanência no Brasil, Saint-Hilaire volta a São João d'El Rei e se surpreende com a quantidade de macieiras, pereiras, pessegueiros, damascos e abricós, além de "castanheiros novos" presentes em alguns quintais. Em um pomar, diz ele, "experimentei grande satisfação" ao ver essa variedade de 
frutas misturadas às comuns jabuticabeiras e bananeiras. "Comi um damasco e uma manga, achando-as excelentes", completa ${ }^{44}$. As comuns bananeiras têm para ele valor especial. Sigamos seu relato.

Nota-se que todas as vezes que descrevo vilas e aldeias das regiões auríferas, refiro-me ao plantio das bananeiras junto de cada casa. Os frutos dessas imensas ervas, muito sadios e nutritivos, são um grande recurso para os pobres, que os comem com farinha e milho ${ }^{45}$.

As bananeiras são presenças quase unânimes nos quintais mineiros e seu fruto é parte do gosto costumeiro da alimentação das Minas. Planta herbáceoarborescente do gênero Musa, tem três espécies comuns no Brasil e na América Central e produz os frutos em cachos grandes ${ }^{46}$. Adstringentes e ricos em vitamina C, cálcio e fósforo eles são grandes reservas alimentares para as populações, em qualquer estação do ano, e daí decorre sua popularidade. Ingeridos crus, cozidos, assados, fritos ou em doces, complementam o cotidiano alimentar da população. A florescência da bananeira é, também, comestível e vai eventualmente à mesa dos mineiros. Além disso, suas folhas são forrageiras suplementares para o gado bovino e as fibras das bainhas de seu pseudocaule servem de matéria-prima a um rico artesanato utilitário e lúdico.

De tão comuns e por suas qualidades e características vegetais e visuais, as bananeiras e seus frutos enriquecem o vocabulário metafórico das gentes das Minas (e do Brasil) que designa de "banana" a pessoa sem energia (palerma, abobadol e diz de quem está à beira da pobreza que "passa a pão e banana". Além disso, "plantar bananeira" é expressão figurativa para designar a atitude de ficar com os pés para cima, apoiando-se nas mãos, em referência à imagem enganadora da bananeira, que tem raízes e caule subterrâneos e pseudocaule aparente.

Sobre os quintais de Vila Rica, John Mawe, estrangeiro que passa pelo território mineiro entre 1809 e 1810, diz:

Os jardins, plantados com muito gosto, apresentam em sua disposição espetáculo curioso. Como é difícil encontrar em todo o flanco da montanha espaço plano de trinta pés quadrados, remediaram essa falta aplainando espaços uns sobre os outros, a distâncias iguais e sustentando-os por muros pouco elevados; escadas conduzem de uns a outros. Esses terraços me parecem o verdadeiro império da Flora, porque jamais vira tal profusão de belas flores. Há, também, excelentes hortaliças de toda espécie, tais como alcachofras, aspargos, espinafre, repolhos, feiião e batatas. Existem frutos indígenas que se aperfeiçoariam, sem dúvida, com melhor sistema de cultivo. $\bigcirc$ pessegueiro parece ser a única árvore europeia de fruto exótico aqui introduzida até agora; floresce de maneira surpreendente ${ }^{47}$.

Como se depreende da citação, a preocupação é com o conhecimento, o seu registro e as possibilidades de aproveitar os produtos com novos sistemas de cultivo e adaptação, reforçando a ideia sempre presente de pressupor a utilidade do conhecimento para auferir riquezas à humanidade. Loreai Kury
44. Cf. Auguste de SaintHilaire (1974, p. 112).

45. Ibid. (p. 116).

46. As três espécies de bananeiras são Musa paradisiaca; Musa cavendishii e Musa sapientum, dando origem a dezenas de variedades.

47. Cf. John Mawe (1978, p. 122 , grifo nosso). 
48. Ver Lorelai Kury (2004), com base em Catherine Duprat (1993). interpreta essa vontade utilitária como parte de um princípio primordial no pensamento intelectual europeu, mas principalmente francês, do final do século XVIII: a "filantropia", desígnio de amor à humanidade e busca de auxílio para o seu bem-estar ${ }^{48}$.

Perspectivas muito agradáveis e salutiferas da paisagem urbana

Thomas Ender, em aquarela pintada a partir de sua visita à cidade de Mariana (Figura 4), retrata a paisagem equilibrada entre casario e áreas "vazias" dos quintais, colocando-os em primeiro plano, talvez, na tentativa de ressaltar a importâncias dessas estruturas para a urbe. De forma similar à Planta do Tejuco, a diversidade vegetal é caracterizada pela técnica e sensibilidade do aquarelista, pressupondo a percepção de delimitações espaciais distintas para árvores de frutas, canteiros das hortas e edificações. Denota, claramente, a lógica de atendimento à topografia e à proximidade ou distância da morada. Sem régua ou esquadro, a ordem não é simétrica, mas atende a funções específicas de cada estrutura na relação com a morada e os seus habitantes. 
Thomas Ender, como outros artistas e naturalistas de seu tempo, é pintor que denota a preocupação humboldtiana com a produção de imagens no processo de observação da natureza ${ }^{49}$. A imagem articula-se organicamente com o texto narrativo e, para nós historiadores é, efetivamente, texto.

Interessante observar na aquarela a representação do jardim do antigo Palácio Novo dos Senhores Bispos, idealizado por D. Frei Cipriano de São José, bispo diocesano de 1798 a 1817 - à esquerda inferior da imagem (Figura 4), em detalhe na sequência do texto (Figura 5). A chácara da Olaria foi doada por José de Torres Quintanilha ao Seminário Nossa Senhora da Boa Morte, para que o primeiro bispo de Mariana, D. Frei Manuel da Cruz, construísse a residência dos bispos. A construção tem continuidade com D. Frei Domingos da Encarnação Pontével e com D. Frei Cipriano de São José. Conhecido como Palácio da Olaria ou Palácio Novo (para diferenciá-lo do Palácio Velho, casa do Conde de Assumar e primeira residência episcopal), seu jardim foi um investimento de D. Frei Cipriano ${ }^{50}$. Simétrico e expressando uma estética europeia na construção de jardins públicos e privados, a representação contrasta com a organização pragmática - sem ordem e sem simetria, como queria Saint-Hilaire - dos quintais domésticos.

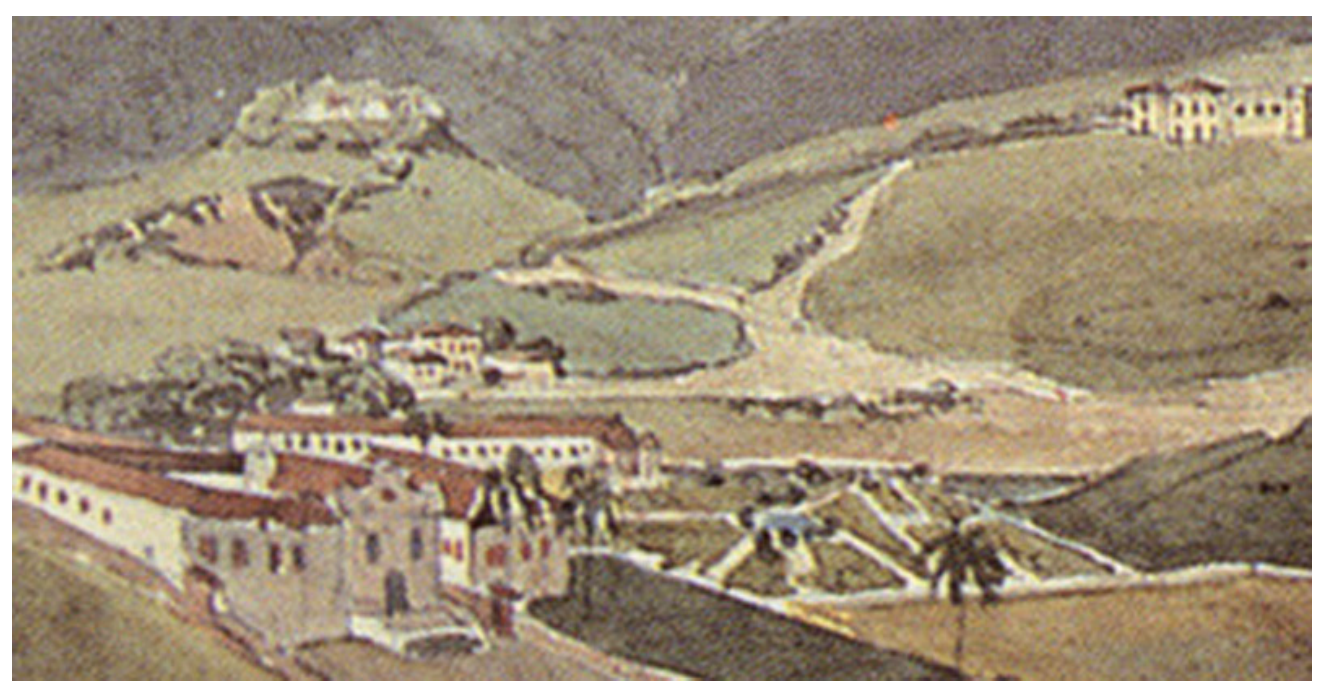

Figura 5 - Thomas Ender. Mariana (MG), detalhe, 1817, aquarela. Fonte: Aquarela completada e corrigida por Thomas Ender, segundo esboço de Johann Emmanuel Pohl; ilustração da obra Viagem ao Interior do Brasil. Viena, 1832.

Naturalmente que essa observação de Saint-Hilaire traduz uma sensibilidade estética neoclássica que pensava os jardins europeus e não os espaços de produção dos quintais, marcados por uma racionalidade cotidiana utilitarista, aderida à realidade dos interesses, das aptidões, dos terrenos, dos arruamentos e do diálogo entre espaços domésticos e públicos.
49. Thomas Ender (Viena, 3 de novembro de 1793 Viena, 28 de setembro de 1875) foi um pintor austríaco que deve ser incluído entre os chamados "pintores viajantes". Veio ao Brasil na época do príncipe regente D. João VI. Destacou-se como aquarelista. Acompanhou a missão científica de Johann Baptiste von Spix e Carl Friedrich Philipp von Martius ao Brasil, onde permaneceu entre $1817 \mathrm{e}$ 1818. Nesse período, produziu uma vasta obra de registro do que viu, principalmente no Rio de Janeiro e em São Paulo. Sobre o artista, ver: Paulo Berger et alii (1990); Jõao Fernando de Almeida Prado (1955); Gilberto Ferrez (1976) e Robert Wagner (1994).

50. Ver Moacir Rodrigo de Castro Maia (mimeo) e Raimundo Trindade (1953). Para um estudo mais verticalizado sobre o espaço urbano de Mariana, ver Cláudia Damasceno Fonseca (1995). 
51. O Padre José Joaquim Viegas de Meneses (Vila Rica, 1778 - Vila Rica, $1^{\circ}$ de julho de 1841) foi um sacerdote, editor e jornalista, sendo considerado o "Pai da Imprensa Mineira". Abandonado por seus pais de sangue, foi criado por Anna da Silva Teixeira de Meneses. Iniciou os estudos aos 11 anos de idade, em Sumidouro e Mariana, concluindo-os em Coimbra, juntamente com o sacerdócio. Em Portugal, aprendeu o ofício de tipografia e a calcografia com o frei José Marianno da Conceição Velloso, na Typographia Chalcographica, Typoplastica e Litteraria do Arco do Cego. Retornando ao Brasil, executou a primeira impressão da história de Minas Gerais, quando, a pedido
O "jardim episcopal" não é um quintal. Acima visualizado em aquarela do Padre Viegas (Figura 6) - que retrata a casa da residência episcopal vista da janela do meio da mesma casa, no seu reverso, donde se vê também o seminário e parte da cidade de Mariana -, ele atende à uma outra lógica, marca de uma civilidade que poderia configurar, aos olhos de Auguste de Saint-Hilaire e de Thomas Ender, espaço de construção humana mais alinhado aos preceitos daquilo que ambos configuravam como um jardin des plantes. Feito com régua, esquadro e compasso, simetria e ordem, expressava uma estética europeia na construção de jardins públicos e privados. Essa estética, familiar a eles e contrastante com a organização pragmática, "sem ordem e sem simetria" dos quintais domésticos, teve um exemplar marianense nas suas narrativas escritas ou aquareladas.

A imagem da aquarela de Ender (Figura 4) remete-nos, ainda, à referência que José Joaquim da Rocha faz da cidade, em seu Geografia histórica da capitania de Minas Gerais. Ele diz sobre a primeira cidade das Minas: "É salutífera, os ares são temperados e produz muita fruta, como bananas, ananases, mamões e laranjas." Naturalmente que tal produção é oriunda dos quintais domésticos das moradias Mariana ${ }^{52}$.

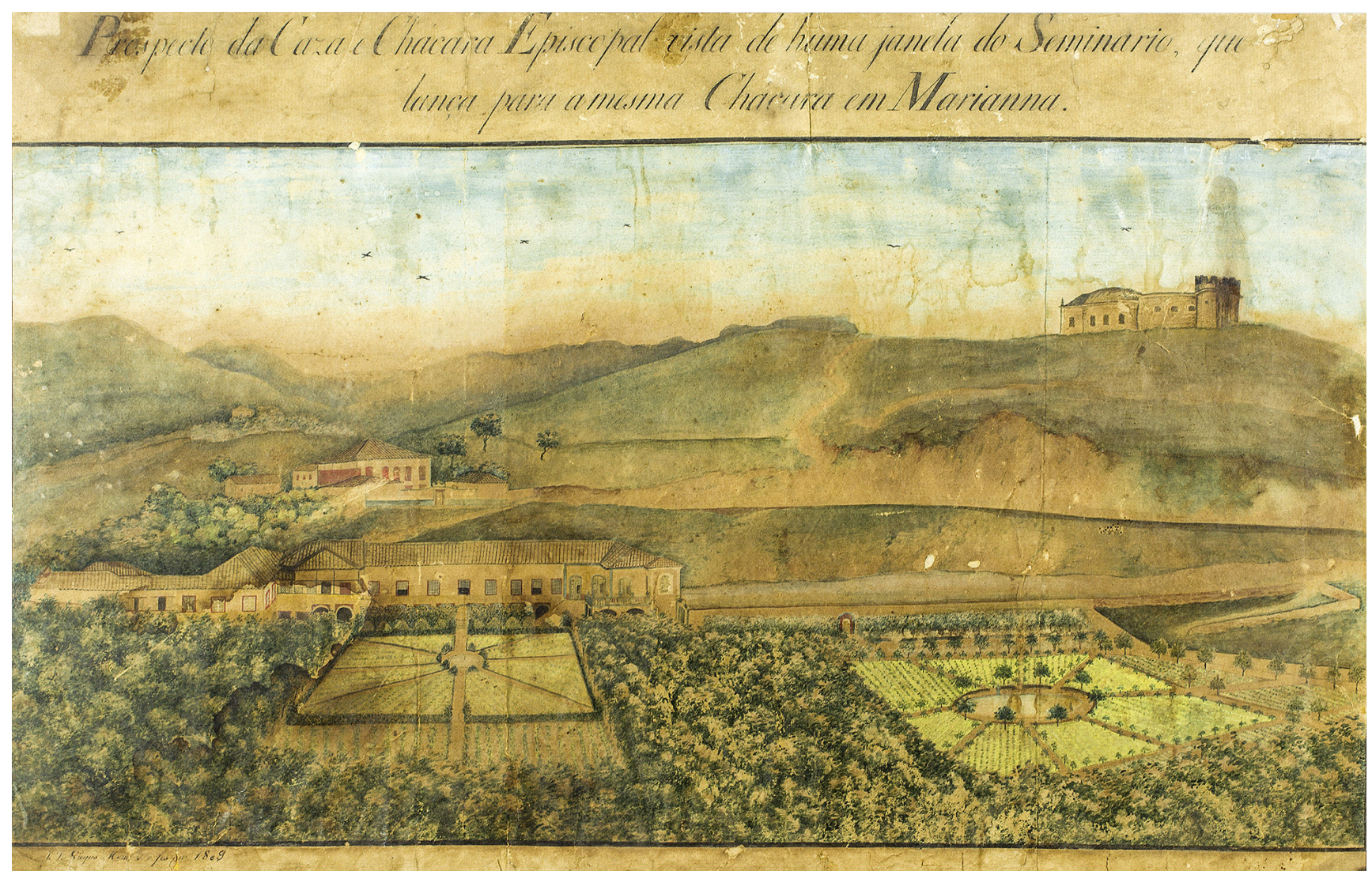

Figura 6 - José Joaquim Viegas de Menezes ${ }^{51}$. Prospecto da Caza e Chácara Episcopal vista de huma janela do Seminário, que lança para a mesma Chácara em Marianna, 1809, aquarela sobre papel, $31 \times 53,5 \mathrm{~cm}$, acervo do Museu Arquidiocesano de Mariana. Fonte: Paulo Mendes Campos (1985, p.48). Original sob a guarda do Museu Arquidiocesano de Mariana. 
A documentação das Câmaras das Vilas de Minas Gerais no século $X V I I I$, em seus variados processos de controle da ordem social, também é profícua em informar sobre procedimentos e ordenações que visam resolver as contingências da urbe. Há neste sentido, e relacionadas ao nosso tema, determinações para coibir e punir a saída para as ruas de porcos criados nos quintais, ordens de limpezas de córregos que banham os quintais das moradas, fiscalização do uso de águas públicas que por eles passam. A diversidade dessa documentação a transforma em rica fonte de pesquisa.

As fiscalizações camarárias também nos informam sobre a construção de cercas nos limites dos quintais e o risco de a vontade privada prejudicar moradores vizinhos ou o público em geral, principalmente nas questões ligadas ao acesso às águas dos córregos que serviam para o abastecimento dos moradores nos chafarizes das vilas. Os quintais "com água dentro" davam responsabilidades extras a seus donos. Assim, em Vila Rica, no dia 13 de janeiro de 1742, três moradores solicitam à Câmara licença para colocarem cercas em seus quintais. Reclamam que os vizinhos da rua dos fundos causam enormes prejuízos ao deixarem entulhos que sujam seus quintais e o córrego que passa por eles e deságua na rua. Argumentam que as cercas não prejudicariam pessoa alguma, mas, ao contrário, seriam de utilidade para todos ${ }^{53}$. Confirma-se aqui a estreita relação dos quintais e seus limites com o arruamento e o abastecimento de água dos aglomerados urbanos. Essa questão está, no entanto, em investigação e será objeto de outros textos.

\section{Conclusão}

Aqui se apresentou um mínimo sobrevoo sobre os espaços rurais e, sobretudo, urbanos das Minas Gerais setecentistas e de início dos anos oitocentos, quando a visão dos quintais dá a dimensão de uma paisagem em busca de ordenação. Eles são lugares da família, entre a casa e a rua. Da intimidade daquela e da sua intermediação entre a publicidade destas últimas. Mas são, principalmente, espaços da domesticidade. Quando muito, de uma sociabilidade fraterna ou conflituosa com a vizinhança. Têm a dimensão da segurança dada pela moradia e a da visibilidade dada pelas relações com a sociedade. Antes de tudo, no entanto, são territórios da materialidade cotidiana em seus elementos mais condizentes com os aspectos familiares da vida. Não há, assim, como refletir sobre - quintal sem pensar a casa de morada, sem perscrutar a sua ligação com os espaços arruados. Essa temática será aprofundada na sequência de uma pesquisa não terminada e com acréscimo documental significativo, tanto do ponto de vista da tipologia documental quanto em acréscimos quantitativos de documentos da administração local e dos Inventários post mortem referentes a outras localidades do espaço pesquisado.

A interpretação sobre a rede de significados construídos socialmente sobre os quintais, urbanos e rurais, poderá nos levar a perceber elementos do então governador da capitania, imprimiu, nas oficinas da Casa da Moeda, um poema que homenageava o próprio governador, em 1807. Utilizou-se da técnica da calcografia. Em 13 de outubro de 1823 , o padre José Joaquim Viegas de Meneses fundou o primeiro jornal de Minas Gerais, denominado $O$ Compilador Mineiro, que circulou até o dia 9 de janeiro de 1824

52. Cf. José Joaquim da Rocha (1995, p. 96).

53. Ver Arquivo Público Mineiro (1742, notação CC, cx. 144, rolo 543). 
importantes da complexa cultura que envolve os espaços domésticos, seus quintais e as sociabilidades que conformam seus territórios. Penso ser importante nessa busca um diálogo com textos documentais e com literaturas, além de uma perspectiva conceitual em torno da representação social sobre esses lugares, na tentativa de buscarmos o "real" ou o "social" por meio de suas representações materiais e simbólicas.

Os quintais são passado presentificado ou presente construído de permanências. Eles colocam em contato espaços, lugares e paisagens que formam territórios de confluência entre modos de ver e de representar o mundo que não se definem exatamente como urbanos ou rurais. Evidenciam sentidos novos revelados ou ocultados por uma urbanidade que produz imagens em profusão, tanto reais - como os cenários, as arquiteturas e as paisagens construídas -, quanto metafóricas, pela literatura, pintura, poesia, discursos sobre a qualidade de vida, sobre a saúde e tantos outros. E esses discursos se apresentam em todos os tempos. Podemos lê-los. Podemos, por meio deles, frequentar as hortas e os pomares de nossos quintais.

\section{REFERÊNCIAS}

\section{DOCUMENTAÇÃO PRIMÁRIA}

\section{MANUSCRITAS}

Arquivo Público Mineiro. notação CC, cx. 144, rolo 543.

Arquivo Público Mineiro, Câmara Municipal de Ouro Preto. cx. 19. doc. 48.

Biblioteca Antonio Tôrres (IPHAN) - Diamantina - MG.

Inventário $011,1^{\circ}$ Of., Maço 33, 1797, com Testamento anexo.

Inventário 043, $1^{\circ}$ Of., Maço 47, 1805.

Inventário 030, $1^{\circ}$ Of., Maço 54, 1806.

Inventário 038, $2^{\circ}$ Of., Maço 175, 1810. 


\section{IMPRESSAS}

MAWE, John. Viagens ao interior do Brasil. Belo Horizonte: Itatiaia; São Paulo: Edusp, 1978.

ROCHA, José Joaquim da. Geografia histórica da capitania de Minas Gerais: descrição geográfica, topográfica, histórica e política da capitania de Minas Gerais: memória histórica da capitania de Minas Gerais. Belo Horizonte: Fundação João Pinheiro; Centro de Estudos Históricos e Culturais, 1995.

ROSÁRIO, Frei António do. Frutas do Brasil numa nova, e ascetica Monarchia, consagrada à Santissima Senhora do Rosario. Fac-símile da edição de Lisboa: Officinia de Antonio Pedrozo Galram, 1702.

SAINT-HILAIRE, Auguste de. Voyage dans les provinces de Rio de Janeiro et de Minas Geraes. Paris: Grimbert et Dorez, libraires, 1850. Disponível em: <gallicalabs.bnf.fr/ark:/12148/ bpt6k98747b.image>

Viagens pelas províncias do Rio de Janeiro e Minas Gerais. Belo Horizonte: Itatiaia; São Paulo: Edusp, 1975.

Viagem pelo distrito dos diamantes e litoral do Brasil. Belo Horizonte: Itatiaia; São Paulo: Edusp, 1974.

\section{LIVROS, ARTIGOS E DISSERTAÇÕES}

ALGRANTI, Leila Mezan. Famílias e vida doméstica. In: NOVAIS, Fernando Antônio; SOUZA, Laura de Mello e (Orgs.). História da vida privada no Brasil: cotidiano e vida privada na América portuguesa. São Paulo: Companhia das Letras, 1997. p. 83-154.

BARREIRO, José Carlos. Imaginário e viajantes no Brasil do século XIX: cultura e cotidiano, tradição e resistência. São Paulo: Ed. Unesp, 2002.

BELUZZO, Ana Maria. A propósito do Brasil dos Viajantes. Revista USP, São Paulo, n. 30, p. 9-19, jun.-ago. 1994.

BERGER, Paulo et al. Pintura e pintores do Rio antigo. Rio de Janeiro: Kosmos, 1990.

BORREGO, Maria Aparecida de Menezes. Códigos e práticas: o processo de constituição urbana de Vila Rica colonial (1702-1748). São Paulo: Annablume; Fapesp, 2004.

BRAUDEL, Fernand. Civilização material, economia e capitalismo séculos XV-XVIII: estruturas do cotidiano. São Paulo: Martins Fontes, 1995.

CAMPOS, Paulo Mendes (Coord.). Mariana: arte para o céu. Belo Horizonte: Comissão PróRestauração da Catedral e Órgão da Sé de Mariana, 1985.

CARLES, Marjolaine. Des eaux, de l'or, des fontaines: politique de l'eau à Vila Rica au XVIIIe siècle (Minas Gerais, Brésil) (mimeo). 
CARVALHO, Vânia Carneiro de. Cultura material, espaço doméstico e musealização. Varia História, Belo Horizonte, v. 27, p. 443-469, 2011.

COSTA, Antônio Gilberto at. al. Cartografia de Minas Gerais: da capitania à província. Belo Horizonte: Editora UFMG, 2002. (Coleção de Cartas, Plantas e Mapas).

DUPRAT, Catherine. Pour l'amour de l'humanité. In: Les temps des philanthropes: la philanthropie parisienne des Lumières à la monarchie de Juillet. Paris: CTHS, 1993.

EDUARDO, Marcio Freitas. Território, trabalho e poder: por uma geografia relacional. Campoterritório: Revista de Geografia Agrária, Uberlândia v.1, n.2, p. 173-195, ago. 2006.

FARGE, Arlette. La vie fragile: violence, pouvoirs et solidarities à Paris au XVIIIe siècle. Paris: Hachette, 1986.

. Le peuple et les choses: Paris au XVIIIe siècle. Paris: Bayard, 2015.

Vivre dans la rue à Paris au XVIIe siècle. Paris: Gallimard, 1992.

FARIA, Sheila de Castro. A colônia em movimento: fortuna e família no cotidiano colonial. Rio de Janeiro: Nova Fronteira, 1998.

FERREZ, Gilberto. O Brasil de Thomas Ender 1817. Rio de Janeiro: Fundação João Moreira Salles, 1976.

FONSECA, Cláudia Damasceno. Arraiais e vilas d'el rei: espaço e poder nas Minas setecentistas. Belo Horizonte: Editora UFMG, 2011.

. Des terres aux villes de l'or: pouvoirs et territoires urbains au Minas Gerais (Brésil, XVIIIe siècle). Lisboa: Fundação Calouste Gulbenkian, 2003.

Mariana: gênese e transformação de uma paisagem cultural. 1995. Dissertação (Mestrado) - Instituto de Geociências, Universidade Federal de Minas Gerais, Belo Horizonte, 1995.

O espaço urbano de Mariana: sua formação e suas representações. In: Termo de Mariana: história e documentação. Ouro Preto: Editora da UFOP, 1998.

GARCIA, Tristan. Forme et objet, un traité des choses. Paris: PUF, 2011.

HAESBAERT, Rogério. Territórios alternativos. São Paulo: Editora Contexto, 2006.

HOLANDA, Sérgio Buarque de. Metais e pedras preciosas. In: História geral da civilização brasileira. $7^{\mathrm{a}}$ ed. t.I, v. 2. Rio de Janeiro: Bertrand Brasil, 1993, p. 259-310.

KURY, Lorelai. Auguste de Saint-Hilaire, viajante exemplar. Revista Intellèctus, Rio de Janeiro: UERJ, ano II, v. I, 2004. Disponível em: <http://www.intellectus.uerj.br/Textos/Ano2n1/ Texto\%20de\%20\%20Lorelai\%20Kury.pdf>.

. Homens de ciência no Brasil: impérios coloniais e circulação de informações (1780-1810).

História, Ciências, Saúde - Manguinhos, Rio de Janeiro, v. 11 (suplemento 1), p. 109-129, $2004 a$. 
KURY, Lorelai. La politique des voyages en France au début du XIXe siècle et la culture scientifique d'Auguste Saint-Hilaire. In: LAISSUS, Yves (Org.). Les naturalistes français en Amérique du Sud: XVIe-XIXe siècles. Paris: CTHS, 1995.

. Viajantes naturalistas no Brasil oitocentista: experiência, relato e imagem. História, Ciências, Saúde-Manguinhos, Rio de Janeiro, v. VIII (suplemento), p. 863-880, 2001.

LISBOA, Karen Macknow. Olhares estrangeiros sobre o Brasil do século XIX. In: MOTA, Carlos Guilherme (Org.). Viagem incompleta. São Paulo: Editora SENAC, 2000.

MAIA, Moacir Rodrigo de Castro. Uma quinta portuguesa no interior do Brasil: o bispo D. Frei Cipriano e o magnífico jardim do antigo palácio Episcopal de Mariana. (mimeo).

MATA, Sérgio Ricardo da. Chão de Deus: catolicismo popular, espaço e proto-urbanização em Minas Gerais, Brasil: séculos XVIII-XIX. Berlin: Wissenschaftlicher Verlag Berlin, 2000.

MENESES, José Newton Coelho. Escalas espaço-temporais e história cultural: reflexão de um historiador sobre o espaço como categoria de análise. In: PAIVA, Eduardo França; AMANTINO, Márcia; IVO, Isnara Pereira. (Org.). Escravidão, mestiçagens, ambientes, paisagens e espaços. São Paulo: Annablume, 2011. v. 3, p. 55-79.

MENESES, Ulpiano Toledo Bezerra de. A cultura material no estudo das sociedades antigas. Revista de História, São Paulo, n.115, p.103-117, jul./dez. 1983.

Memória e Cultura Material: documentos pessoais no espaço público. Estudos Históricos, Rio de Janeiro, v. 11, n. 21, 1998.

MILLIOT, Vincent. Les cris de Paris ou le peuple travesti: les répresentations des petits métiers parisiense: XVIe-XVIIIe siècles. Paris: Publications de La Sorbonne, 2014.

MOREIRA LEITE, Miriam. Livros de viagem: 1803-1900. Rio de Janeiro: Editora da UFRJ, 1997.

PRADO, João Fernando de Almeida. Tomas Ender: pintor austríaco na corte de D. João VI no Rio de Janeiro. São Paulo: Companhia Editora Nacional, 1955.

ROCHE, Daniel. História das coisas banais: nascimento do consumo: séculos XVII-XIX. Rio de Janeiro: Rocco, 2000.

SANTOS, Milton. Espaço e método. São Paulo: Nobel, 1985.

SANTOS, Douglas. A reinvenção do espaço: diálogos em torno da construção do significado de uma categoria. São Paulo: UNESP, 2002.

SILVA, Fabiano Gomes da. Pedra e Cal: os construtores em Vila Rica no século XVIII (1730-1800). 2007. Dissertação (Mestrado) - Faculdade de Filosofia e Ciências Humanas, Universidade Federal de Minas Gerais, Belo Horizonte, 2007.

SILVA, Valéria Mara da. Nascidas do sol e da chuva: Minas Gerais e o combate às saúvas (1928-1936). 2007. Dissertação (Mestrado) - Faculdade de Filosofia e Ciências Humanas, Universidade Federal de Minas Gerais, Belo Horizonte, 2007. 
TEDESCHI, Denise Maria Ribeiro. Águas urbanas: as formas de apropriação das águas nas Minas: século XVIII. São Paulo: Alameda, 2014.

TRINDADE, Raimundo (Cônego). Arquidiocese de Mariana: subsídios para sua história. $2^{\mathrm{a}}$ ed. Belo Horizonte: Imprensa Oficial, 1953.

WAGNER, Robert. Thomas Ender in Brasilien. Viena: Adeva, 1994. 